\title{
Dominant inheritance of retinal ganglion cell resistance to optic nerve crush in mice
}

\author{
Yan Li, Sheila J Semaan, Cassandra L Schlamp and Robert W Nickells*
}

Address: Department of Ophthalmology and Visual Sciences, University of Wisconsin, Madison, Wisconsin, USA

Email: Yan Li - yli88@yahoo.com; Sheila J Semaan - sjsemaan@wisc.edu; Cassandra L Schlamp - clschlamp@wisc.edu; Robert W Nickells* - nickells@wisc.edu

* Corresponding author

Published: 5 March 2007

BMC Neuroscience 2007, 8:19 doi:10.1/86/147|-2202-8-19
Received: 23 October 2006

Accepted: 5 March 2007

This article is available from: http://www.biomedcentral.com/I47I-2202/8/19

(C) $2007 \mathrm{Li}$ et al; licensee BioMed Central Ltd.

This is an Open Access article distributed under the terms of the Creative Commons Attribution License (http://creativecommons.org/licenses/by/2.0), which permits unrestricted use, distribution, and reproduction in any medium, provided the original work is properly cited.

\begin{abstract}
Background: Several neurodegenerative diseases are influenced by complex genetics that affect an individual's susceptibility, disease severity, and rate of progression. One such disease is glaucoma, a chronic neurodegenerative condition of the eye that targets and stimulates apoptosis of CNS neurons called retinal ganglion cells. Since ganglion cell death is intrinsic, it is reasonable that the genes that control this process may contribute to the complex genetics that affect ganglion cell susceptibility to disease. To determine if genetic background influences susceptibility to optic nerve damage, leading to ganglion cell death, we performed optic nerve crush on 15 different inbred lines of mice and measured ganglion cell loss. Resistant and susceptible strains were used in a reciprocal breeding strategy to examine the inheritance pattern of the resistance phenotype. Because earlier studies had implicated Bax as a susceptibility allele for ganglion cell death in the chronic neurodegenerative disease glaucoma, we conducted allelic segregation analysis and mRNA quantification to assess this gene as a candidate for the cell death phenotype.
\end{abstract}

Results: Inbred lines showed varying levels of susceptibility to optic nerve crush. DBA/2J mice were most resistant and $B A L B / C B y J$ mice were most susceptible. FI mice from these lines inherited the DBA/2J phenotype, while N2 backcross mice exhibited the BALB/cByJ phenotype. F2 mice exhibited an intermediate phenotype. A Wright Formula calculation suggested as few as 2 dominant loci were linked to the resistance phenotype, which was corroborated by a Punnett Square analysis of the distribution of the mean phenotype in each cross. The levels of latent Bax mRNA were the same in both lines, and Bax alleles did not segregate with phenotype in N2 and F2 mice.

Conclusion: Inbred mice show different levels of resistance to optic nerve crush. The resistance phenotype is heritable in a dominant fashion involving relatively few loci. Bax was excluded as a candidate gene for this phenotype.

\section{Background}

The influence of complex genetics on neurodegenerative diseases such as Alzheimer's Disease, Parkinson's Disease, and Multiple Sclerosis, is evidenced by the consideration that family history is a significant risk factor for candidate patients [1-3]. Although interacting loci may influence a variety of different factors, one common element is the process of neuronal cell death, which predominantly occurs by apoptosis $[4,5]$. Consequently, consideration of the genes that affect susceptibility to disease should 
include those that affect both the response(s) of neurons to damaging stimuli and the process of cell death itself. Several studies, using screening strategies of inbred mouse lines, have reinforced the concept that genetic background has an influence on the level of susceptibility to neuronal damage [6-9]. At least 3 loci have been mapped, for example, that affect neuronal susceptibility to the Parkinsonian neurotoxin 1-methyl-4-phenyl-1,2,3,6-tetrahydropyridine (MPTP) $[10,11]$.

Primary open angle glaucoma is also a multifactorial neurodegenerative disease with a strong familial component [12-14]. This disease affects an estimated 60 million individuals worldwide [15] and is characterized by the progressive apoptotic death of retinal ganglion cells and the degeneration of the optic nerve [16-18]. All forms of glaucoma are associated with critical elevations in intraocular pressure (IOP), but humans exhibit a wide range of susceptibility to this stimulus. Although most glaucoma patients have a higher than average IOP, the majority of ocular hypertensives will never develop the disease $[19,20]$. Conversely, there is a significant percentage of glaucoma sufferers who have normal or below normal IOP [17]. In the majority of people with glaucoma, however, lowering IOP regardless of the starting level, has a beneficial effect in slowing the progression of the disease. This clinical history of disease progression and response to treatment has led to the concept that there is variable susceptibility to the damaging effects of eye pressure [2022].

One genetically regulated component that could influence ganglion cell susceptibility is the cell death process itself. In response to a majority of cell death stimuli, retinal ganglion cell death in mice is restricted to Bax-dependent, intrinsic apoptosis, a pathway common to many neurons of the CNS. This pathway is activated during development [23], after acute optic nerve lesion [24], or in chronic spontaneous glaucoma [25]. Since apoptosis is an intrinsic genetic process, differences in alleles of genes that affect cell death could influence ganglion cell susceptibility to a damaging stimulus. Reducing Bax gene dosage, for example, reduces the level of latent Bax mRNA and can completely abrogate ganglion cell death after optic nerve crush or in glaucoma [25]. To explore the possibility that genetic background could affect neuronal cell death, we first investigated if different strains of inbred mice exhibited different levels of ganglion cell loss in response to a standardized lesion of the optic nerve (mechanical crush). Here, we report that inbred mice have different susceptibilities to optic nerve crush, and that the resistant phenotype can be inherited in a relatively simple Mendelian fashion. Although Bax plays a critical role in regulating ganglion cell susceptibility, we excluded it as a candidate gene for this trait. Identification of the gene(s) that affect the susceptibility of retinal ganglion cells to damaging stimuli could help elucidate part of the genetic complexity of glaucoma and other neurodegenerative diseases.

\section{Results \\ Inbred mice exhibit quantitative differences in ganglion cell loss after optic nerve crush}

Retinal ganglion cell loss after optic nerve crush occurs over a period of 3 weeks, with the most rapid period of loss occurring between the first and second weeks [26]. We chose to examine the period of 2 weeks after optic nerve crush in order to assess the process of cell death while still at an intermediate stage (see Methods section). A bar graph of the mean $( \pm$ SD) of cells remaining in the crushed retina for 10 mice in 15 different lines is shown in Figure 1. Representative micrographs of control and crushed Nissl-stained retinas from mice at each end and the middle of this distribution are shown in Figure 2. Mice exhibited a range of cell loss after 2 weeks from $26.3 \%$ to $47.4 \%$ of the total neurons in the ganglion cell layer. A matrix of $P$ values comparing each of the means against each other ( $t$-tests) is shown in Table 1 . Both sets of inbred lines with similar genetic backgrounds (DBA and C57BL mice) had comparable amounts of cell loss based on statistical testing. There were no significant correlations between coat color and susceptibility or known neurosensory defects and susceptibility (data not shown).

\section{Ganglion cell prevalence in DBA/2J and $B A L B / c B y$ J mice}

From the initial screen of 15 inbred lines, DBA/2J mice were selected as the most resistant, and BALB/cByJ mice were selected as the most susceptible. A potential caveat in this study, however, is that cell loss was estimated as a percentage of the total neurons present in the ganglion cell layer. Since ganglion cells are not the only neurons present in this layer, our analysis of cell loss would only be accurate if ganglion cells comprised a similar percentage of the neurons in each strain. To assess this, we calculated the total number of neurons in the ganglion cell layers of DBA/2J and BALB/cByJ mice by counting cells in Nissl-stained whole mounts of untreated retinas. We also estimated the total number of ganglion cells in each strain by counting axons in sections of the optic nerves. Results of this analysis are shown in Table 2. Although DBA/2J mice have more total neurons in their ganglion cell layer they also have a proportionately higher number of ganglion cells, resulting in the same percentage of ganglion cells in both strains $(\sim 60 \%)$.

\section{Dominant inheritance of ganglion cell resistance to crush}

To confirm these as resistant and susceptible strains, we performed optic nerve crush on increased numbers of mice from each strain (28 DBA/2J and $31 \mathrm{BALB} / \mathrm{cByJ}$ mice). Consistent with the initial screen, DBA/2J mice 


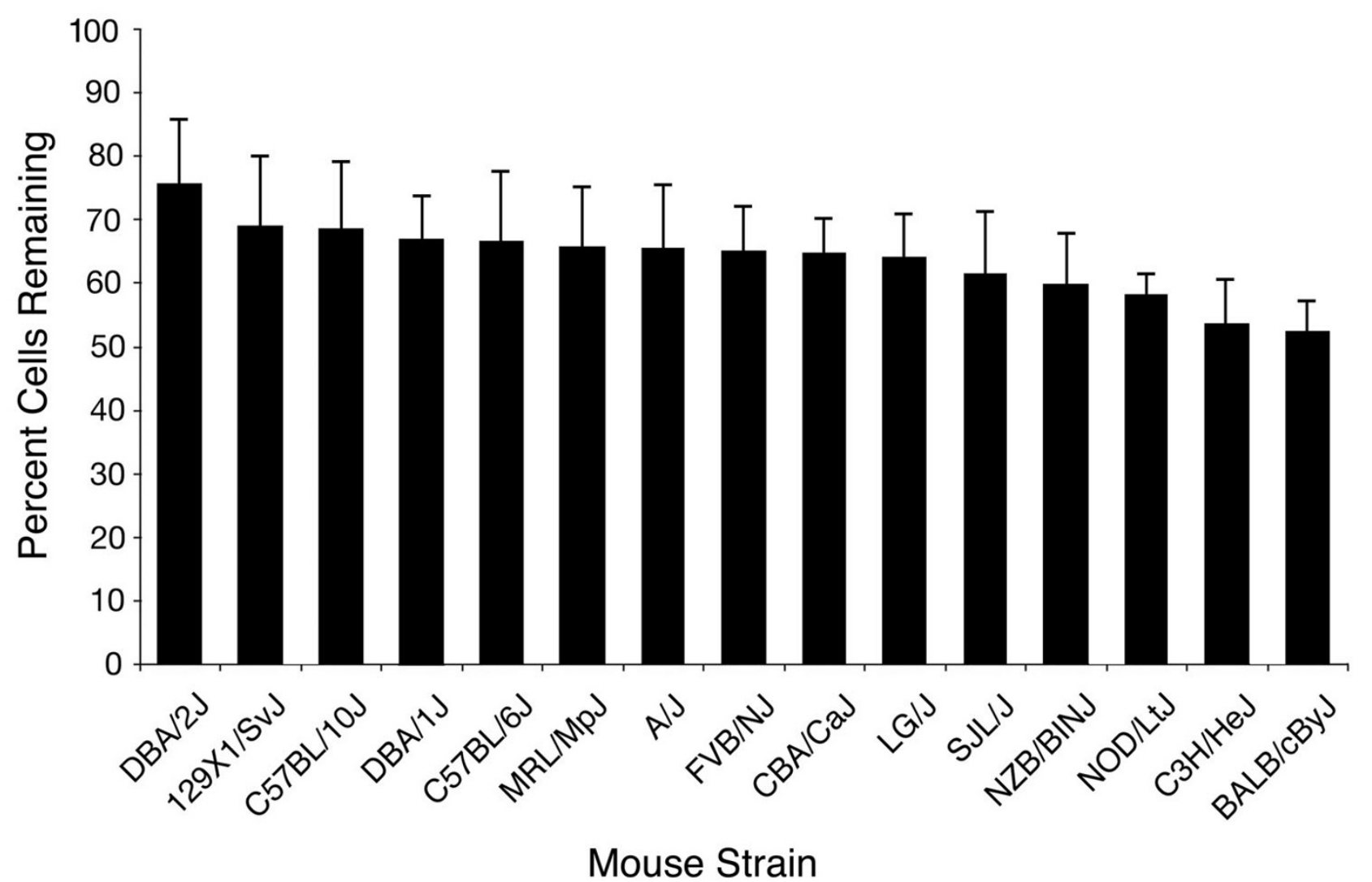

Figure I

Inbred mice exhibit different sensitivity to optic nerve crush. Histographs showing the percentage of cells remaining in the retinal ganglion cell layer 2 weeks after optic nerve crush. The data shown is the mean ( \pm SD) of 10 mice from each strain and reflects the percentage of cells present in the experimental retina relative to the fellow control eye.

exhibited significantly less cell loss than BALB/cByJ mice (Figures $3 \mathrm{~A}$ and $3 \mathrm{~B}, P=3.8 \times 10^{-8}, t$ test). To determine whether the susceptibility to optic nerve crush was genetically controlled, crosses were performed between the two strains. F1 mice $(\mathrm{n}=28)$ inherited the optic nerve crushresistance phenotype exhibited by DBA/2J mice (Figure $3 \mathrm{C}, P=0.178$ vs $\mathrm{DBA} / 2 \mathrm{~J}$ and $P=0.001$ vs $\mathrm{BALB} / \mathrm{cByJ}$ mice). N2 mice $(n=55)$, exhibited a shift toward a more susceptible phenotype (Figure $3 \mathrm{D}, P=2.2 \times 10^{-6}$ vs DBA/ $2 \mathrm{~J}$ and $P=0.15$ vs $\mathrm{BALB} / \mathrm{cByJ})$. F2 mice $(\mathrm{n}=56)$ yielded an intermediate phenotype after optic nerve crush with a bias toward the resistance phenotype (Figure 3E, $P=0.017$ vs $\mathrm{DBA} / 2 \mathrm{~J}$ and $P=0.006$ vs $\mathrm{BALB} / \mathrm{cByJ})$. By assigning a mean value for cell loss for the resistant and susceptible phenotypes, cell loss in each of the crosses was accurately predicted by the expected distribution of 2 dominant alleles using a Punnett Square method of analysis (data not shown).
A statistical estimation of the number of affecting loci was made using a modified Wright Formula, which takes into account the means and variances of the F1 mice and the recurrent backcross parental strain $[27,28]$. This formula yielded a value of 1.3, suggesting that only a few genes were contributing to the inheritance pattern of this phenotype, consistent with the Punnett Square analysis.

\section{Elimination of Bax as a contributing allele to the resistance phenotype}

The proapoptotic gene Bax is essential for ganglion cell death after optic nerve crush [24] and in chronic spontaneous glaucoma [25]. Reduced Bax expression in mice heterozygous for a $B a x$ knock-out allele has varying effects on neurons, depending on genetic background [25,29], an effect that appears to be related to the level of latent Bax mRNA from the endogenous wild type gene (S. Semaan and R. Nickells, unpublished observation) [30]. Bax+/- 


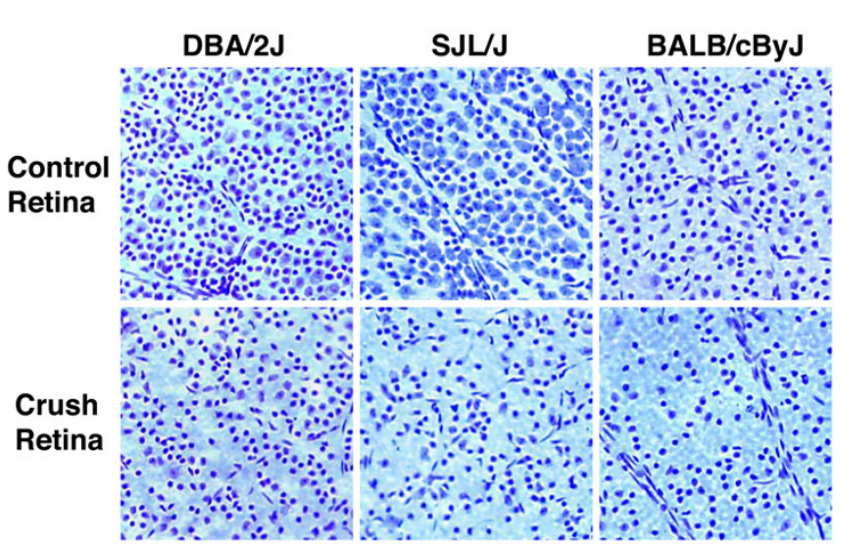

Figure 2

Nissl-stained ganglion cell layers from control and experimental eyes. Each panel is representative of the mid-central superior retina of the inbred lines shown. Two weeks after optic nerve crush, the retinas exhibit a loss of cells with larger somas and nuclei with prominent nucleoli, features characteristic of retinal ganglion cells. DBA/2J, SJL/J, and $\mathrm{BALB} / \mathrm{cBy}$ mice exhibit resistant, moderately resistant, and susceptible phenotypes to optic nerve crush, respectively. Magnification 200x.

DBA/2J mice are completely resistant to optic nerve crush [25] and have relatively low levels of neuronal Bax expression. Interestingly, DBA/2J mice were the most resistant to the same crush protocol of all the inbred mice examined.

To examine Bax as a candidate gene for the resistant phenotype, we first quantified Bax mRNA levels in the brains of DBA/2J and BALB/cByJ mice using RNase Protection Assays (RPA). Both lines express a BAX protein with the same predicted amino acid sequence (data not shown), so if Bax was associated with the resistance phenotype, we predicted that BALB/CByJ mice would have higher levels of latent neuronal Bax mRNA. Quantitative examination of Bax mRNA levels in BALB/cByJ and DBA/2J mice showed no statistical difference between the two lines $(P=0.49$, Figure 4). In a second experiment, we mapped the segregation of DBA/2J (D2) and BALB/cByJ (B) Bax alleles in $\mathrm{N} 2$ and F2 mice used in this study. A scatter plot of phenotype as a function of Bax genotype is shown in Figure 5. Evaluation of these data was made comparing mice with the $B a x^{\mathrm{B} / \mathrm{B}}$ background against $B a x^{\mathrm{D} 2 / \mathrm{B}}$ and $B a x^{\mathrm{D} 2 / \mathrm{D} 2}$ mice (animals with the D2 allele were either pooled together as one group or compared as separate groups). None of the 4 possible comparisons yielded a significant association between the Bax genotype and the resistance phenotype (ANOVA, $P=0.150$ for $B a x^{\mathrm{B} / \mathrm{B}}$ vs. $B a x^{\mathrm{D} 2 / \mathrm{B}}$ and $B a x^{\mathrm{D} 2 / \mathrm{D} 2} \mathrm{~N} 2$ and F2 mice combined, $\mathrm{n}=106 ; P=0.356$ for $B a x^{\mathrm{B} / \mathrm{B}}$ vs. $B a x^{\mathrm{D} 2 / \mathrm{B}}$ vs. $B a x^{\mathrm{D} 2 / \mathrm{D} 2} \mathrm{~N} 2$ and F2 mice, $\mathrm{n}=106 ; P=0.987$ for $B a x^{\mathrm{B} / \mathrm{B}}$ vs. $B a x^{\mathrm{D} 2 / \mathrm{B}}$ and $B a x^{\mathrm{D} 2 / \mathrm{D} 2} \mathrm{~F} 2$ mice only, $\mathrm{n}=53$; and $P$ $=0.575$ for $B a x^{\mathrm{B} / \mathrm{B}}$ vs. $B a x^{\mathrm{D} 2 / \mathrm{B}}$ vs. $B a x^{\mathrm{D} 2 / \mathrm{D} 2}$ F2 mice only, $\mathrm{n}$ $=53$ ).

\section{Discussion}

We screened 15 different strains of inbred mice for cell loss caused by optic nerve crush and identified differing levels of susceptibility. DBA/2J mice were identified as the most resistant strain, and $\mathrm{BALB} / \mathrm{CByJ}$ mice were identified as the most susceptible strain. Offspring of crosses involving these two lines inherited the resistance phenotype, while a backcross of the F1 mice to the susceptible parental strain, yielded a population of mice with the susceptible phenotype. The progeny of the F1 intercross inherited an intermediate phenotype with a bias toward resistance. The pattern of inheritance exhibited by the crosses sug-

Table I: Matrix of $P$ values of the mean cell counts from all inbred lines

\begin{tabular}{|c|c|c|c|c|c|c|c|c|c|c|c|c|c|c|}
\hline Strain & $\mathrm{DBA} / 2 \mathrm{~J}$ & 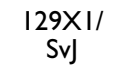 & $\begin{array}{c}\text { C57BL/ } \\
10]\end{array}$ & DBA/IJ & $\begin{array}{c}\mathrm{C} 57 \mathrm{BL} / \\
6 \mathrm{~J}\end{array}$ & $\begin{array}{l}\text { MRL/ } \\
\text { MpJ }\end{array}$ & $A / J$ & $\mathrm{FVB} / \mathrm{NJ}$ & $\mathrm{CBA} / \mathrm{CaJ}$ & LG/J & SJL/J & $\begin{array}{l}\text { NZB/ } \\
\text { BINJ }\end{array}$ & $\begin{array}{c}\text { NOD/ } \\
\text { Lt] }\end{array}$ & $\begin{array}{c}\mathrm{C} 3 \mathrm{H} / \\
\mathrm{HeJ}\end{array}$ \\
\hline BALB/cByJ & 0.00012 & 0.00017 & 0.0002 & 0.00001 & 0.0008 & 0.0005 & 0.0008 & 0.0001 & 0.00003 & 0.0004 & 0.01 & 0.015 & 0.003 & 0.339 \\
\hline $\mathrm{C} 3 \mathrm{H} / \mathrm{HeJ}$ & 0.001 & 0.0017 & 0.0022 & 0.0005 & 0.006 & 0.005 & 0.007 & 0.002 & 0.001 & 0.005 & 0.048 & 0.066 & 0.05 & \\
\hline NOD/Lt & 0.001 & 0.004 & 0.004 & 0.0007 & 0.015 & 0.014 & 0.019 & 0.0065 & 0.003 & 0.013 & 0.18 & 0.29 & & \\
\hline NZB/BINJ & 0.0096 & 0.025 & 0.033 & 0.024 & 0.069 & 0.08 & 0.095 & 0.077 & 0.07 & 0.126 & 0.35 & & & \\
\hline SJL/J & 0.022 & 0.06 & 0.07 & 0.08 & 0.138 & 0.17 & 0.189 & 0.189 & 0.194 & 0.265 & & & & \\
\hline LG/J & 0.04 & 0.138 & 0.162 & 0.187 & 0.28 & 0.344 & 0.36 & 0.398 & 0.42 & & & & & \\
\hline CBA/CaJ & 0.034 & 0.138 & 0.166 & 0.209 & 0.3 & 0.386 & 0.4 & 0.46 & & & & & & \\
\hline $\mathrm{FVB} / \mathrm{NJ}$ & 0.045 & 0.165 & 0.197 & 0.258 & 0.336 & 0.42 & 0.436 & & & & & & & \\
\hline $\mathrm{A} / \mathrm{J}$ & 0.087 & 0.239 & 0.276 & 0.359 & 0.407 & 0.489 & & & & & & & & \\
\hline MRL/MpJ & 0.079 & 0.236 & 0.275 & 0.365 & 0.413 & & & & & & & & & \\
\hline C57BL/6J & 0.125 & 0.322 & 0.363 & 0.476 & & & & & & & & & & \\
\hline DBA/IJ & 0.088 & 0.308 & 0.354 & & & & & & & & & & & \\
\hline C57BL/I0J & 0.194 & 0.458 & & & & & & & & & & & & \\
\hline $129 \times \mid / S v J$ & 0.214 & & & & & & & & & & & & & \\
\hline
\end{tabular}

A table showing head-to-head statistical comparisons of the mean cells remaining of each strain of inbred mice. $P$ values ( $t$-test) shown in bold font indicate a significant difference in the mean values between the compared mice. Based on the criterion of cell loss in the ganglion cell layer 2 weeks after crush, DBA/2J mice exhibited the greatest resistance to optic nerve crush, while BALB/cByJ mice exhibited the greatest susceptibility. 
Table 2: Total neuron and ganglion cell counts from DBA/2J and BALB/cByJ mice

\begin{tabular}{cccc}
\hline Strain & GCL Neurons* & Total Axons** & Percent RGCs \\
\hline DBA/2j & $118416 \pm 12313$ & $72175 \pm 17554$ & 61.0 \\
BALB/cByj & $90788 \pm 11200$ & $54740 \pm 8484$ & 60.3 \\
\hline
\end{tabular}

A table showing the comparison of total neurons counted in the ganglion cell layer (GCL) and the percentage of this layer that are made up of retinal ganglion cells (RGC) in DBA/2J and BALB/cByJ mice. RGCs make up a similar percentage of the neurons present in this layer of both DBA/2 J and $B A L B / c B y$ mice $(61 \%$ and $60.3 \%$, respectively), which validates the methodology of quantifying cell loss as a percentage of the total number of neurons present in the GCL of each strain.

*Neurons were identified from Nissl-stained whole mounts of untreated retinas and counted. A calculation was made of the neuron density/mm ${ }^{2}$ from a minimum of four $200 \times$ microscopic fields of at least 30 non-experimental retinas per strain. The total number of neurons was then calculated by multiplying the density by the total retinal area measured in the whole mounts using Image Pro software.

**Axon counts were generated from a minimum of three $1000 \times$ fields per section ( 3 sections per nerve) of 5 individual optic nerves per strain. The density of the axons was then calculated and total axon number was determined by multiplying the density by the total nerve area measured in the section using Image Pro software.

gests involvement of dominant alleles and a Punnett Square analysis to determine the frequency of inheritance of 2 dominant genes, with complete penetrance, accurately predicted the mean cell loss observed in each cross. Similarly, a Wright formula calculation estimated that a minimum of 1.3 loci were affecting this phenotype. Analysis of Bax expression level and allelic segregation with phenotype excluded this gene as a candidate for one of the affecting alleles.

\section{The Influence of Genetic Background on Neurodegeneration in Inbred Mice}

Several studies have reported that inbred strains of mice exhibit variable susceptibility to neurodegenerative stimuli, but there has been no consistent correlation between strain and susceptibility. C57BL/6 mice, which were relatively crush resistant in our study, are more susceptible to MPTP exposure, spinal chord injury, and experimental autoimmune encephalitis (EAE) than other strains. Conversely, BALB/c mice (crush susceptible) are resistant to EAE and MPTP, but exhibit a similar susceptibility as C57BL/6 mice to spinal chord injury. C57BL/10 mice (crush resistant) and B10.PL mice, which are EAE resistant and susceptible, respectively, both exhibit less severe injury after spinal chord lesion than other strains [9]. Part of the differences exhibited by some inbred strains may reside in their variable abilities to mount an immune response, which can affect the progression and severity of certain neurodegenerative diseases [9,31]. The lack of a correlation between mouse strains and their susceptibility to different degenerative challenges is not surprising. Each challenge is potentially unique to different subsets of neurons (such as cells in the substantia nigra being susceptible to MPTP). It is also likely that different diseases elicit different damaging stimuli, which in turn can activate alternative pathways leading to neuronal death [24,32].

\section{Genes that affect Retinal Ganglion Cell Death}

Recently, Libby et al [14] outlined two broad classes of genes that can affect ganglion cell susceptibility to damage in glaucoma. The first class modulates extrinsic susceptibility of ganglion cells. This set of genes is predicted to influence the response of non-ganglion cells (e.g., glia) to ocular hypertension, the composition and modulation of the extracellular matrix, the density and regulation of retinal vasculature of the optic nerve head, and possibly the immune responses in the eye. The second class of genes modulates the intrinsic susceptibility of ganglion cells. These latter genes are predicted to directly affect ganglion cell survival. By the nature of our screen, which directly activates apoptosis by axonal lesion, we predict that we are most likely selecting for intrinsic susceptibility genes.

Many genes could be intrinsic susceptibility factors. Retinal ganglion cell death follows the basic molecular pathways identified in other neurons and several of the key genes involved in cell death could affect ganglion cell susceptibility to damaging stimuli. We examined the Bax gene as a candidate based on the evidence that this gene was critical for ganglion cell death in a variety of situations [23-25]. Several other genes, however, are also known to influence ganglion cell death. Proapoptotic genes active in ganglion cells include $c$-Jun $[33,34]$ and c-JUN terminal Kinase (Jnk) [35], p53 [36], Bim [37], Apaf-1 [34], poly(ADP-ribose) polymerase (Parp) [38], and several caspases [39-42]. Interestingly, a significant association has been reported between p53 (TP53) haplotypes and primary open angle glaucoma in humans [43].

In addition to proapoptotic genes, ganglion cells are also significantly affected by the expression of antiapoptotic genes. Ganglion cells express $B c l X$, whose expression decreases during the initial stages of apoptosis [44]. Upregulation of this gene in ganglion cells enhances their survival [45]. Similarly, transgenic mice that overexpress the $B c l X$ homolog, $B c l 2$, exhibit nearly complete abrogation of ganglion cell death during development and after optic nerve transection $[46,47]$. Since downregulation of endogenous $B c l X$, along with other normally expressed genes $[48,49]$, is an early event in ganglion cell apoptosis, 

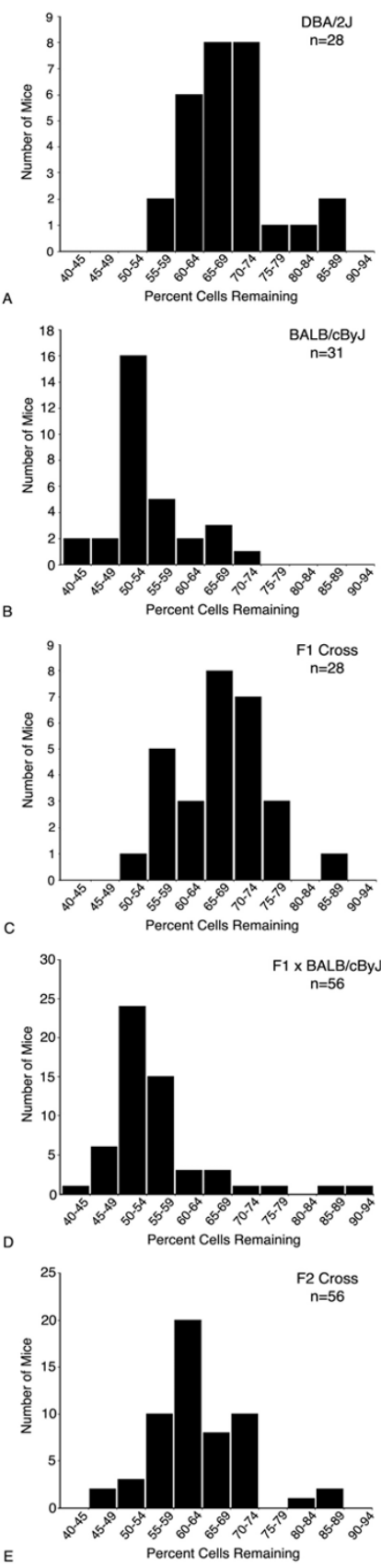

Figure 3

Resistance to optic nerve crush is heritable. Histographs showing the distribution of cell loss in 5 different populations of mice. (A) DBA/2J parental strain. (B) BALB/cByJ parental strain. (C) FI generation of mice from DBA/2J and $\mathrm{BALB} / \mathrm{cBy}$ J parents. These offspring inherit a level of resistance comparable to the DBA/2J parental strain. (D) N2 backcross generation of mice ( $\mathrm{FI}$ mice crossed with $\mathrm{BALB} / \mathrm{cBy}$ ] mice). These mice exhibit a shift toward the BALB/cByJ pattern of lowered resistance to optic nerve crush. (E) F2 generation of mice (FI intercross). These mice exhibit an intermediate pattern of resistance.

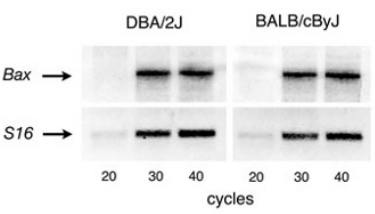

A

Figure 4

Latent Bax mRNA levels are similar in the CNS of DBA/2J and BALB/CByJ mice. (A) An ethidium bromidestained gel (reverse image) showing the RT-PCR products for Bax and S/ 6 mRNAs at increasing numbers of cycles. Bax mRNA appears equally abundant in both strains of mice. This observation was confirmed with RNase Protection Assays (B). The level of Bax message was normalized to the level of SI 6 and this value was plotted for each mouse examined. No statistical difference was observed in the Bax mRNA abundance between the two strains $(P=0.98, t$-test $)$.

any variation that reduces this process and allows these proteins to persist could affect the normal apoptotic program.

Damaged ganglion cells in mammals also exhibit an early stress response that includes the up-regulation of heat shock proteins $[50,51]$ and iron-regulating genes including transferrin and ceruloplasmin [52,53]. These latter genes may also act as antioxidants by scavenging free radicals formed from mitochondria during the cell death process [54].

Although Bax has been eliminated as a candidate gene in this population of mice, clearly there are other genes that could affect the cell death phenotype. We are currently in the process of conducting a genome wide screen to identify potential loci that affect the resistance phenotype.

Using Mice to Identify Susceptibility Alleles for Glaucoma In this study, we used inbred mice to assess if genetic background affects the susceptibility of retinal ganglion cells to a lesion of the optic nerve. These experiments do not directly address whether the same genes that affect ganglion cells after optic nerve crush will also be susceptibility alleles for ganglion cells exposed to elevated levels of IOP, the principal damaging insult in glaucoma. The actual mechanism linking high IOP with ganglion cell damage is still unresolved, but some studies suggest that elevated pressure causes increased sheer forces on the optic nerve at the level of the scleral canal and lamina cribrosa $[55,56]$. This has lead to the hypothesis that increased IOP 


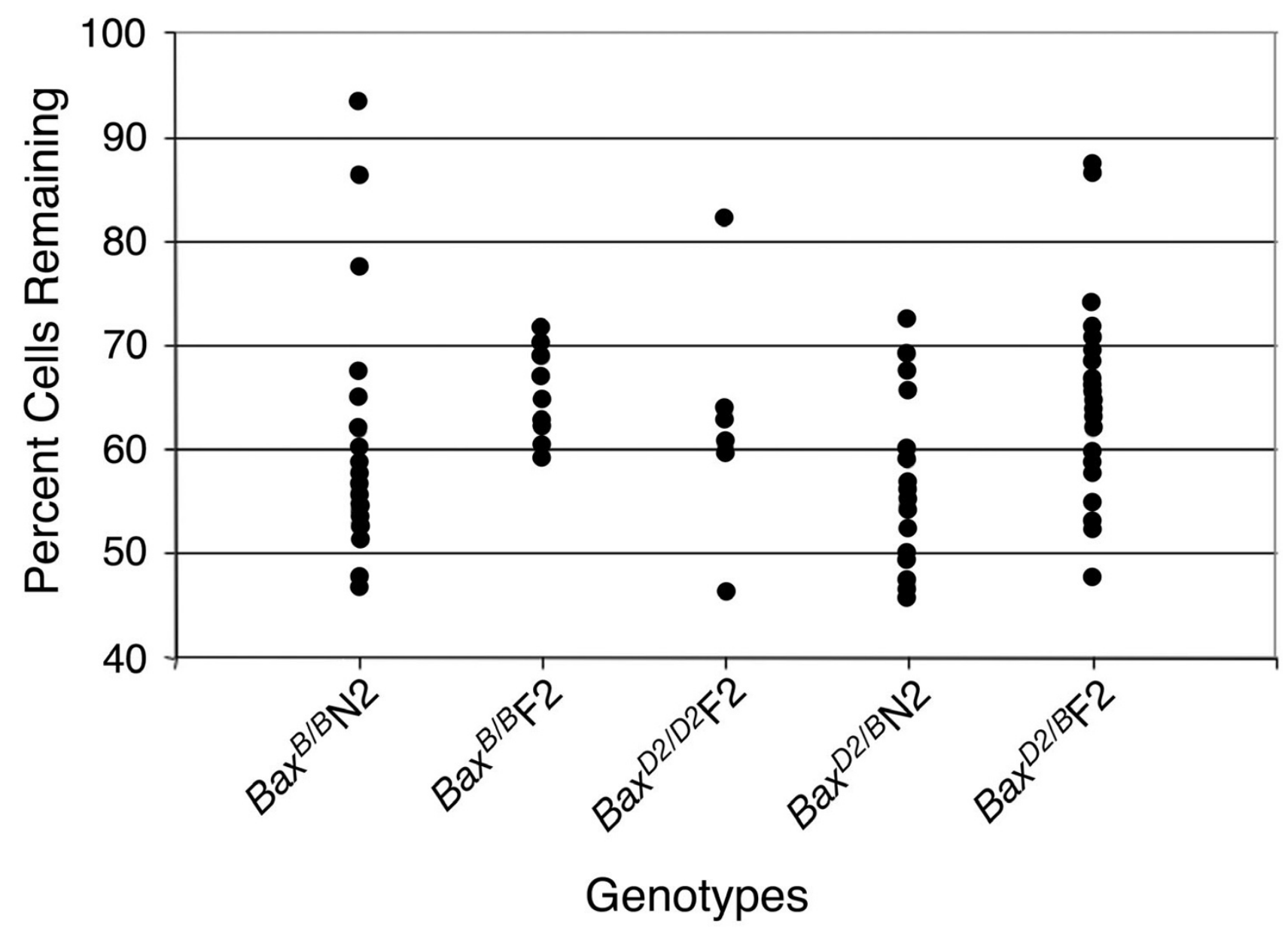

\section{Figure 5}

Scatter plot showing the distribution of the percent cells remaining as a function of Bax allele and breeding population. Mice from the N2 backcross and F2 populations were genotyped at position 23.0 on chromosome 7, near the location of the Bax allele. Each group of points represents individual animals carrying either a contributing allele from a BALB/ $\mathrm{CByJ}$ parent (B) or a DBA/2J parent (D2). ANOVA analysis indicated no significant association between the resistance phenotype and the segregation of the Bax allele, excluding this gene as the principal contributor of this phenotype.

causes mechanical damage to axons at this region $[57,58]$, and it is becoming more evident that this is the region of initial damage in glaucoma [59-61]. Although the concept of sheer stress acting directly on the axons is attractive, and could be analogous to our crush insult, there are several other mechanisms by which IOP can induce damage in this region. These include reducing the perfusion of microvessels in the nerve head and the focal activation of astrocytes and microglia. Consequently, it is possible that optic nerve crush may act differently on ganglion cells than elevated IOP.

Regardless of the nature of the insult, there is some evidence, however, both optic nerve crush and elevated IOP result in a similar cell death response within the ganglion cells themselves. Ganglion cell apoptosis is Bax-dependent $[24,25]$ and leads to the activation of caspases $[39,41,42]$ in both conditions. In addition, ganglion cells undergo early losses of gene expression before the activation of detectable ganglion cell loss [48] after crush and in glaucoma. In view of the similarities of the cell death pathways activated by both conditions, we predict that the susceptibility alleles that affect ganglion cell death after crush will also affect ganglion cell loss in glaucoma. A critical test of this hypothesis is to first identify the loci that affect the crush phenotype and then assess how the same gene(s) affect ganglion cell loss in glaucoma. For example, $\mathrm{DBA} / 2 \mathrm{~J}$ mice naturally develop a form of secondary 
chronic inherited glaucoma [62-65]. Although DBA/2J mice are the most resistant strain assayed in our study, they still exhibit variable susceptibility to elevated IOP as they age, which eventually leads to ganglion cell loss. Breeding the susceptibility alleles inherent in BALB/cByJ mice onto the DBA/2J background, however, could result in mice that develop a more aggressive form of glaucoma. Thus, in response to the same levels of elevated IOP, these modified mice may develop earlier onset of ganglion cell loss or perhaps an accelerated rate of retinal degeneration.

\section{Conclusion}

In summary, our examination of ganglion cell loss after optic nerve crush in inbred mice indicates that genetic background influences the susceptibility of these cells. Experiments using a reciprocal breeding strategy demonstrate that the resistance phenotype is inherited in a dominant fashion and involves relatively few loci. Extending this observation to identify the genes at these loci, may help elucidate some of the alleles that contribute to susceptibility to ocular hypertension leading to glaucoma in humans.

\section{Methods \\ Inbred mice}

Animals were handled in accordance with the Association for Research in Vision and Ophthalmology Statement on the use of animals for research. All inbred mice were purchased from the Jackson Laboratory (Bar Harbor, ME). Five female and 5 male mice, aged 6 weeks, were obtained from each of the following lines: 129X1/2J, A/J, BALB/ cByJ, C3H/HeJ, C57BL/6J, C57BL/10J, CBA/CaJ, DBA/1J, DBA/2J, FVB/NJ, LG/J, MRL/MpJ, NOD/LtJ, NZB/BINJ, $\mathrm{SJL} / \mathrm{J}$. Lines were chosen to obtain a cross section of mice with different coat colors, varying degrees of neurosensory defects (including 8 lines with hearing loss due to homozygosity for the $C d h 23^{\text {ahl }}$ allele and 3 lines with photoreceptor degeneration due to homozygosity for the Pde6brd1 allele), and at least 2 pairs of lines with similar genetic backgrounds (C57BL/6J - C57BL/10J and DBA/1J - DBA/2J). DBA/2J mice also exhibit spontaneous chronic glaucoma associated with the loss of ganglion cells $[62,65]$. This disease affects older mice and was not expected to influence the response of young mice to an acute lesion.

Mice were aged to 8 weeks, at which time they underwent optic nerve crush on the left eye (see below). Mice were allowed to recover and were maintained for another 2 weeks before being euthanized for cell counting. This protocol was strictly adhered to for all the mice examined in this study. New animals were obtained from the Jackson Laboratory for all matings that required the original inbred parental strains. A reciprocal breeding strategy was used for subsequent matings to generate N2 backcrossed mice $(\mathrm{F} 1 \times$ susceptible parental strain) and F2 mice $(\mathrm{F} 1$ intercross).

\section{Optic nerve crush and ganglion cell counting}

For optic nerve crush surgery, mice were anesthetized with ketamine $(6 \mathrm{mg} / \mathrm{mL})$ and xylazine $(0.4 \mathrm{mg} / \mathrm{mL})$. The crush protocol was performed as described previously [26] using an intraorbital approach. Only the left eye of each mouse underwent the procedure. The loss of ganglion cells is a continuous process over a 3-4 week period, therefore we examined the time point at which there was the earliest maximum difference between the resistant and susceptible strains. Both DBA/2J and BALB/cByJ mice exhibit minimal cell loss at one week, followed by a period of rapid cell loss between 1 and 2 weeks. Each strain also exhibits modest cell loss after this point, but the difference between the two is not different than that observed at 2 weeks after crush (data not shown). For this reason, we examined all populations of mice at 2 weeks after optic nerve crush.

To quantify cell loss, mice were euthanized and the superior region of each eye was marked with an ophthalmic cautery prior to enucleation. Each eye was then enucleated and fixed for $1 \mathrm{~h}$ at $22^{\circ} \mathrm{C}$ in $4 \%$ paraformaldehyde in 0.1 $M$ phosphate buffer (pH 7.4) containing $100 \mathrm{mM} \mathrm{NaCl}$ (PBS) followed by rinsing in PBS. An eyecup of the posterior pole was isolated and incubated in PBS containing $0.3 \%$ TritonX-100 (v/v), overnight at $22^{\circ} \mathrm{C}$. Following incubation, the retina was dissected and mounted (ganglion cell layer up) on a glass "Plus" slide (Fisher Scientific, Chicago, IL), dried, and flattened under a coverslip weighted with a $10 \mathrm{~g}$ weight [66]. Dry retinas were stained by painting them with $1 \%$ cresyl violet acetate in $0.25 \%$ acetic acid [67]. Stained retinas were then differentiated and dehydrated in $100 \%$ ethanol, cleared in xylene, and coverslipped. Each slide contained the control and experimental retinas from a single mouse.

For counting cells in the ganglion cell layer, we captured digital images taken at 200× magnification using an Olympus BX40 light microscope (Olympus, Mellville, NY) with a SONY DXC-390 video camera attachment (Sony, New York, NY) and imported them into Image Pro Plus v4.5 (Media Cybernetics, Inc., Silver Springs, MD) quantification software. Parameters were set to automatically identify cells with round nuclei greater than $4 \mu \mathrm{m}$ in diameter and exclude vascular endothelial cells (with spindle-shaped nuclei) and small densely staining cells that are common in the mouse retina [68]. The selection process did not distinguish between ganglion cells and large amacrine cells, but previous studies have estimated the proportion of ganglion cells in this layer to be $40-$ $60 \%$ of the neurons present $[26,68,69]$. The number of cells present in a minimum of 4 microscopic fields, each 
encompassing an area of $0.33 \mathrm{~mm}^{2}$ and taken in the peripheral to midperipheral region around the 4 quadrants of each retina, was counted. In non-experimental retinas, the total numbers of cells ranged from 2055 2913 per field, consistent with previous reports of neuronal cell density in this layer [69]. The numbers of cells present in each retina was taken as the average of these counts and cell loss was calculated in each mouse as the percent change between the control and experimental eyes. Overall, we counted approximately $10 \%$ of the neurons present in each retina, which previous studies have demonstrated provides an accurate estimate of the loss of retinal ganglion cells after optic nerve crush $[25,26,48]$.

Ganglion cell number was also estimated in untreated eyes of DBA/2J and BALB/CByJ mice by axon counting. Briefly, the optic nerves of 5 eyes from each strain were harvested and fixed overnight in $2.5 \%$ glutaraldehyde in PBS and then embedded in glycol methacrylate (JB-4 Plus, PolyScience, Worthington, PA). Transverse sections of 2 $\mu \mathrm{m}$ thick were cut approximately $1 \mathrm{~mm}$ from the globe and stained by silver impregnation to identify axons [67]. Axon counting was conducted as described previously [36] using 3 sections from each nerve.

\section{Ribonuclease protection assays (RPAs)}

Total RNA was isolated from the brains of DBA/2J $(n=24)$ or BALB/cByJ $(n=23)$ mice. Radiolabeled antisense riboprobes for RPA were synthesized from linearized pBKCMV plasmid (Stratagene, La Jolla, CA) templates containing the terminal 127 nucleotides of the murine Bax coding region or nucleotides 55-252 of the murine S16 ribosomal protein coding region. Probe synthesis, purification, hybridization, and RNase digestion conditions were as described previously [48]. Because retinas were used for the quantification of cell loss, RPA assays were performed on total RNA isolated from brain tissue of mice. In some mice, however, we confirmed that the level of Bax mRNA, and the ratio of Bax mRNA to S16 mRNA, was consistent between the 2 CNS tissues (data not shown). RPAs were initiated by precipitating $20 \mu \mathrm{g}$ brain total RNA for Bax or $1 \mu \mathrm{g}$ brain total RNA for $S 16$ with $5 \times$ $10^{5}$ acid precipitable cpm of probe. After hybridization and RNase digestion, protected probes were separated on $0.4 \mathrm{~mm} 8 \mathrm{M}$ urea/6\% polyacrylamide gels, and exposed to BioMax MR film (Kodak, Rochester, NY). Exposure times ranged from overnight to $10 \mathrm{~d}$ at $-80^{\circ} \mathrm{C}$ with an intensifying screen. Band intensities were quantified from densitometric scans of multiple exposures of each gel using $\mathrm{NIH}$ Image software, and confirmed by liquid scintillation counting of the excised bands.

\section{Genotyping mice}

Genomic DNA was isolated from the spleens of N2 backcrossed mice $(n=55)$ and F2 mice $(n=56)$ for genotyp- ing. Bax is located at position 23.0 on chromosome 7 . PCR genotyping analysis was performed for the polymorphic marker D7Mit27 using the primers: 5' TGA ACT GGG GAG GAA AGT TG and 5' AAC ATG AAA AGA CAT TCC CCC. These primers yielded a 218 bp fragment for DBA/ 2J mice and a $182 \mathrm{bp}$ fragment for BALB/cByJ mice and map within $1.5 \mathrm{Mbp}$ of the mouse Bax gene. PCR products were separated on 3\% Meta Phor Agarose (Cambrex, Rockland, ME) gels and the bands were identified by ethidium bromide staining.

\section{Authors' contributions}

RWN (corresponding author) conceived of the study, directed the research, and wrote the manuscript. YL did all the optic nerve crush experiments and phenotyping mice, and made contributions to data analysis and manuscript writing. CLS helped in data analysis and project design and contributed to manuscript preparation. SJS did the Bax mRNA quantification and genotyping of mice.

\section{Acknowledgements}

This work was supported by grants from The Glaucoma Research Foundation and The National Eye Institute (ROI EYI2223 and R03 EYOI634I) to RWN, a CORE grant P30 EY0I 6665 to the Department of Ophthalmology and Visual Sciences, and an unrestricted grant from Research to Prevent Blindness, Inc. The authors are grateful to Dr. Andrew Thliveris and Dr. Simon John for helpful discussions.

\section{References}

I. Huang W, Chengxuan Q, von Strauss E, Winblad B, Fratiglioni L: APOE genotype, family history of dementia, and Alzheimer Disease risk. Arch Neurol 2004, 61:1930-1934.

2. Semchuk KM, Love EJ, Lee RG: Parkinson's disease: a test of the multifactorial etiologic hypothesis. Neurol 1993, 43: I I7I-I I80.

3. Doolittle TH, Myers RH, Lehrich JR, Birnbaum G, Sheremata W, Franklin GM, Nelson LM, Hauser SL: Multiple sclerosis sibling pairs: clustered onset and familial disposition. Neurol 1990 , 40: I546-I552.

4. Shacka JJ, Roth KA: Regulation of neuronal cell death and neurodegeneration by members of the $\mathrm{Bcl}-2$ family: therapeutic implications. Curr Drug Targets CNS Neurol Disorders 2005, 4:25-39.

5. Ekshyyan O, Aw TY: Apoptosis: a key in neurodegenerative disorders. Curr Neurovasc Res 2004, I:355-37I.

6. Tian J, Shi J, Bailey K, Harris JM, Pritchard A, Lambert JC, ChartierHarlin MC, Pickering-Brown SM, Lendon CL, Mann DM: A polymorphism in the angiotensin I-converting enzyme gene is associated with damage to cerebral cortical white matter in Alzheimer's disease. Neurosci Lett 2004, 354:103-106.

7. Li L, Fan M, Icton CD, Chen N, Leavitt BR, Hayden MR, Murphy TH, Raymond LA: Role of NR2B-type NMDA receptors in selective neurodegeneration in Huntington disease. Neurobiol Aging 2003, 24: III3-II2I.

8. Kruger R, Fischer C, Schulte T, Strauss KM, Muller T, Woitalla D, Berg D, Hungs M, Gobbele R, Berger K, Epplen JT, Riess O, Schols L: Mutation analysis of the neurofilament M gene in Parkinson's disease. Neurosci Lett 2003, 35 I:125-129.

9. Kigerl KA, McGaughy VM, Popovich PG: Comparative analysis of lesion development and intraspinal inflammation in four strains fo mice following spinal contusion injury. J Comp Neurol 2006, 494:578-594.

10. Cook R, Lu L, Gu J, Williams RW, Smeyne RJ: Identification of a single QTL, Mptp I, for susceptibility to MPTP-induced substantia nigra pars compacta neuron loss in mice. Mol Brain Res 2003, II 0:279-288.

II. Sedelis M, Hofele K, Schwarting RKW, JHuston JP, Belknap JK: Chromosomal loci influencing the susceptibility to the Parkinso- 
nian neurotoxin |-methyl-4-phenyl-I,2,3,6tetrahydropyridine. J Neurosci 2003, 23:8247-8253.

12. Netland PA, Wiggs JL, Dreyer EB: Inheritance of glaucoma and genetic counseling of glaucoma patients. Int Ophthalmol Clin 1993, 33:101-120.

13. Tielsch JM, Katz J, Sommer A, Quigley HA, Javitt JC: Family history and risk of primary open angle glaucoma: The Baltimore Eye Survey. Arch Ophthalmol 1994, I I 2:69-73.

14. Libby RT, Gould DB, Anderson MG, John SWM: Complex genetics of glaucoma susceptibility. Ann Rev Genomics Hum Genet 2005 , 6:15-44.

15. Quigley HA: The number of persons with glaucoma worldwide. Br J Ophthalmol 1996, 80:389-393.

16. Quigley HA: Open-angle glaucoma. New Engl J Med 1993, 328:1097-II06

17. Nickells RW, Jampel H, Zack DJ: Glaucoma. In Principles and Practice of Medical Genetics Volume III. 4th edition. Edited by: Rimion DL, Connor JM, Pyeritz RE and Korf BR. New York, Churchill Livingstone; 2002:349I-35I2.

18. Nickells RW: The molecular biology of retinal ganglion cell death: caveats and controversies. Brain Res Bull 2004, 62:439-446.

19. Quigley HA, Enger C, Katz J, Sommer A, Scott R, Gilbert D: Risk factors for the development of glaucomatous visual field loss in ocular hypertension. Arch Ophthalmol 1994, I I 2:644-649.

20. Kass MA, Heuer DK, Higginbotham EJ, Johnson CA, Keltner JL, Miller JP, Parrish II RK, Wilson MR, Gordon MO: The ocular hypertension study: A randomized trial determines that topical ocular hypertensive medication delays of prevents the onset of primary open-angle glaucoma. Arch Ophthalmol 2002, 120:701-7I3.

21. Heijl A, Leske MC, Bengtsson B, Hyman L, Bengtsson B, Hussein M: Reduction of intraocular pressure and glaucoma progression. Arch Ophthalmol 2002, 120:1268-1279.

22. Leske MC, Heijl A, Hussein M, Bengtsson B, Hyman L, Komaroff E: Factors for glaucoma progression and the effect of treatment. Arch Ophthalmol 2003, I 21:48-56.

23. Mosinger Ogilvie J, Deckwerth TL, Knudson CM, Korsmeyer SJ: Suppression of developmental retinal cell death but not photoreceptor degeneration in Bax-deficient mice. Invest Ophthalmol Vis Sci 1998, 39:1713-1720.

24. Li Y, Schlamp CL, Poulsen KP, Nickells RW: Bax-dependent and independent pathways of retinal ganglion cell death induced by different damaging stimuli. Exp Eye Res 2000, 71:209-2I3.

25. Libby RT, Li Y, Savinova OV, Barter J, Smith RS, Nickells RW, John SWM: Susceptibility to neurodegeneration in glaucoma is modified by Bax gene dosage. PLoS Genet 2005, 1:17-26.

26. Li Y, Schlamp CL, Nickells RW: Experimental induction of retinal ganglion cell death in adult mice. Invest Ophthalmol Vis Sci 1999, 40: 1004-1008.

27. Lander ES, Botstein D: Mapping Mendelian factors underlying quantitative traits using RFLP linkage maps. Genetics 1989, 121:185-199.

28. Doerge RW: Mapping and analysis of quantitative trait loci in experimental populations. Nat Rev Genet 200I, 3:43-52.

29. Deckwerth TL, Elliot JL, Knudson CM, Johnson Jr. EM, Snider WD, Korsmeyer SJ: BAX is required for neuronal death after trophic factor deprivation and during development. Neuron 1996, I 7:40I-4II.

30. Semaan SJ, Li Y, Babcic V, John SWM, Nickells RW: Differential regulation of the pro-apoptotic gene Bax in DBA/2J and I29B6 inbred mice affects retinal ganglion cell death after optic nerve crush. Invest Ophthalmol Vis Sci 2005, 46:E-Abstract 1279.

31. Kipnis J, Yoles E, Schori H, Hauben E, Shaked I, Schwartz M: Neuronal survival after CNS injury is determined by a genetically encoded autoimmune response. J Neurosci 200I, $21: 4564-4571$.

32. Miller TM, Moulder KL, Knudson CM, Creedon DJ, Deshmukh M, Korsmeyer SJ, Johnson Jr. EM: Bax deletion further orders the cell death pathway in cerebellar granule cells and suggests a caspase-independent pathway to cell death. I Cell Biol I997, 139:205-2 I7.

33. Yoshida K, Behrens A, Le-Niculescu H, Wagner EF, Harada T, Imak J, Ohno S, Karin M: Amino-terminal phosphorylation of c-Jun regulates apoptosis in the retinal ganglion cells by optic nerve transection. Invest Ophthalmol Vis Sci 2002, 43:163|-1635.
34. Lingor P, Koeberle P, Kügler S, Bähr M: Down-regulation of apoptosis mediators by RNAi inhibits axotomy-induced retinal ganglion cell death in vivo. Brain 2005, doi:10.1093/brain/ awh382:

35. Wakabayshi T, Kosaka J, Oshika T: JNK inhibitory kinase is upregulated in retinal ganglion cells after axotomy and enhances BimEL expression levels in neuronal cells. J Neurochem 2005, 95:526-536.

36. Li Y, Schlamp CL, Poulsen G, Jackson M, Griep A, Nickells RW: p53 regulates apoptotic ganglion cell death induced by $\mathbf{N}$ methyl-D-aspartate. Mol Vis 2002, 8:34I-350, http:/l www.molvis.org/molvis/v8/a4I.

37. Näpänkangas U, Lindqvist $N$, Lindholm D, Hallböök F: Rat retinal ganglion cells upregulate the pro-apoptotic $\mathrm{BH}$-only protein Bim after optic nerve transection. Mol Brain Res 2003, I 20:30-37.

38. Weise J, Isenmann S, Bähr M: Increased expression and activation of poly(ADP-ribose) polymerase (PARP) contribute to retinal ganglion cell death following rat optic nerve transection. Cell Death Differ 200I, 8:80I-807.

39. McKinnon SJ, Lenhman DM, Kerrigan-Baumrind LA, Merges CA, Pease ME, Kerrigan DF, Ransom NL, Tahzib NG, Reitsamer HA, Levkovitch-Verbin H, Quigley HA, Zack DJ: Caspase activation and amyloid precursor protein cleavage in rat ocular hypertension. Invest Ophthalmol Vis Sci 2002, 43:1077-1087.

40. Kermer P, Klöcker N, Labes M, Bähr M: Inhibition of CPP32-like proteases rescues axotomized retinal ganglion cells from secondary death in vivo. J Neurosci 1998, 18:4656-4662.

4I. Kermer P, Klocker N, Labes M, Thomsen S, Srinivasan A, Bähr M Activation of caspase-3 in axotomized rat retinal ganglion cells in vivo. FEBS Lett 1999, 25:361-364

42. Kermer P, Ankerhold R, Klocker N, Krajewski S, Reed JC, Bähr M: Caspase-9 involvement in secondary death of axotomized rat retinal ganglion cells in vivo. Brain Res Mol Brain Res 2000, 28: $144-150$

43. Ressiniotis T, Griffiths PG, Birch M, Keers S, Chinnery PF: Primary open angle glaucoma is associated with a specific p53 gene haplotype. J Med Genet 2004, 41:296-298.

44. Levin LA, Schlamp CL, Spieldoch RL, Geszvain KM, Nickells RW: Identification of bcl-2 family genes in the rat retina. Invest Ophthalmol Vis Sci 1997, 38:2545-2553.

45. Kretz A, Kügler S, Happold C, Bähr M, Isenmann S: Excess BcIXL increases the intrinsic growth potential of adult CNS neurons in vitro. Mol Cell Neurosci 2004, 26:63-74.

46. Bonfanti L Strettoi E, Chierzi S, Cenni MC, Liu XH, Martinou JC, Maffei L, Rabacchi SA: Protection of retinal ganglion cells from natural and axotomy-induced cell death in neonatal transgenic mice overexpressing bcl-2. J Neurosci 1996, 16:4|86-4194.

47. Cenni MC, Bonfanti L, Martinou JC, Ratto GM, Strettoi E, Maffei L: Long-term survival of retinal ganglion cells following optic nerve section in adult bcl-2 transgenic mice. Eur J Neurosci 1996, 8: 1735-1745.

48. Schlamp CL, Johnson EC, Li Y, Morrison JC, Nickells RW: Changes in Thyl gene expression associated with damaged retinal ganglion cells. Mol Vis 200I, 7:|92-20|<http://www.molvis.org/ molvis/v7/a27>.

49. Weishaupt JH, Klocker N, Bahr M: Axotomy-induced early down-regulation of POU-IV class transcription factors Brn3a and Brn-3b in retinal ganglion cells. J Mol Neurosci 2005, 26:17-25

50. Park KH, Cozier F, Ong OC, Caprioli J: Induction of heat shock protein $\mathbf{7 2}$ protects retinal ganglion cells in a rat glaucoma model. Invest Ophthalmol Vis Sci 200I, 42: I522-I530.

5I. Krueger-Naug AM, Emsley JG, Myers TL, Currie RW, Clarke DB: Injury to retinal ganglion cells induces expression of the small heat shock protein Hsp27 in the rat visual system. Neurosci 2002, I 1 0:653-665.

52. Levin LA, Geszvain KM: Expression of ceruloplasmin in the retina: induction after optic nerve crush. Invest Ophthalmol Vis Sci 1998, 39:157-163.

53. Farkas RH, Chowers I, Hackam AS, Kageyama M, Nickells RW, Otteson D, Duh E, Wang C, Valenta D, Gunatilaka T, Pease ME, Quigley $H A$, Zack DJ: Increased expression of iron-regulating genes in monkey and human glaucoma. Invest Ophthalmol Vis Sci 2004, 45:|4|0-|4|7. 
54. Green DR, Reed JC: Mitochondria and apoptosis. Science 1998, 28 I: $|309-| 3 \mid 2$.

55. Bellezza AJ, Rintalan CJ, Thompson HW, Downs JC, Hart RT, Burgoyne CF: Deformation of the lamina cribrosa and anterior scleral canal wall in early experimental glaucoma. Invest Ophthalmol Vis Sci 2003, 44:623-637.

56. Ethier CR: Scleral biomechanics and glaucoma - a connection? Can J Ophthalmol 2006, 41:9-1I.

57. Quigley HA, Addicks EM, Green WR, Maumenee AE: Optic nerve damage in human glaucoma: II. The site of injury and susceptibility to damage. Arch Ophthalmol 1981, 99:635-649.

58. Quigley HA, Addicks EM: Regional differences in the structure of the lamina cribrosa and their relation to glaucomatous optic nerve damage. Arch Ophthalmol 1981, 99:137-I43.

59. Pease ME, McKinnon S], Quigley HA, Kerrigan-Baumrind LA, Zack DJ: Obstructed axonal transport of BDNF and its receptor TrkB in experimental glaucoma. Invest Ophthalmol Vis Sci 2000, 41:764-774.

60. Jakobs TC, Libby RT, Ben Y, John SWM, Masland RH: Retinal ganglion cell degeneration is topological but not cell type specific in DBA/2J mice. J Cell Biol 2005, 171:313-325.

61. Schlamp CL, Li Y, Dietz JA, Janssen KT, Nickells RW: Progressive ganglion cell loss and optic nerve degeneration in DBA/2J mice is variable and asymmetric. $B M C$ Neurosci 2006, 7:66.

62. John SWM, Smith RS, Savinova OV, Hawes NL, Chang B, Turnbull D, Davisson M, Roderick TH, Heckenlively JR: Essential iris atrophy, pigment dispersion, and glaucoma in DBA/2J mice. Invest Ophthalmol Vis Sci 1998, 39:951-962.

63. Chang B, Smith RS, Hawes NL, Anderson MG, Zabaleta A, Savinova O, Roderick TH, Heckenlively JR, Davisson MT, John SWM: Interacting loci cause severe iris atrophy and glaucoma in DBA/2 J mice. Nature Genet 1999, 21:405-409.

64. Anderson MG, Smith RS, Hawes NL, Zabaleta A, Chang B, Wiggs JL, John SWM: Mutations in genes encoding melanosomal proteins cause pigmentary glaucoma in DBA/2J mice. Nat Genet 2002, 30:8I-85.

65. Libby RT, Anderson MG, Pang IH, Robinson Z, Savinova OV, Cosma IM, Snow A, Wilson LA, Smith RS, Clark AF, John SWM: Inherited glaucoma in DBA/2J mice: pertinent disease features for studying the neurodegeneration. Vis Neurosci 2005, 22:637-648.

66. Stone J: The Wholemount Handbook. A Guide to the Preparation and Analysis of Retinal Wholemounts. Sydney, Maitland Publishing Pty. Ltd.; 1981:3-23.

67. Bancroft JD, Stevens A: Bielschowsky's silver stain for axons in frozen and paraffin sections (modified). In Theory and Practice of Histological Techniques 3rd edition. Edited by: Bancroft JD and Stevens A. New York, Churchill Livingstone; 1990:347-348.

68. Dräger UC, Olsen JF: Ganglion cell distribution in the retina of the mouse. Invest Ophthalmol Vis Sci 198I, 20:285-293.

69. Jeon CJ, Strettoi E, Masland RH: The major cell populations of the mouse retina. J Neurosci 1998, 18:8936-8946.

Publish with Bio Med Central and every scientist can read your work free of charge

"BioMed Central will be the most significant development for disseminating the results of biomedical research in our lifetime. "

Sir Paul Nurse, Cancer Research UK

Your research papers will be:

- available free of charge to the entire biomedical community

- peer reviewed and published immediately upon acceptance

- cited in PubMed and archived on PubMed Central

- yours - you keep the copyright
BioMedcentral 